
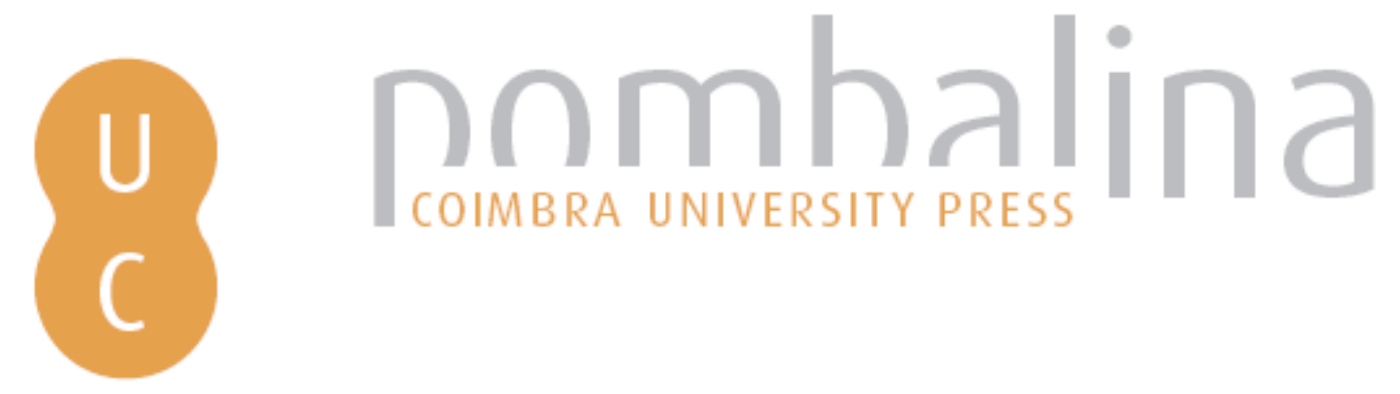

\title{
Norma e transgressão, à luz do paradigma bíblico
}

Autor(es): Ramos, José Augusto M.

Publicado por: Imprensa da Universidade de Coimbra

URL

persistente: URI:http://hdl.handle.net/10316.2/32819

DOI: $\quad$ DOI:http://dx.doi.org/10.14195/978-989-26-0236-3_13

Accessed : $\quad$ 26-Apr-2023 12:54:20

A navegação consulta e descarregamento dos títulos inseridos nas Bibliotecas Digitais UC Digitalis, UC Pombalina e UC Impactum, pressupõem a aceitação plena e sem reservas dos Termos e Condições de Uso destas Bibliotecas Digitais, disponíveis em https://digitalis.uc.pt/pt-pt/termos.

Conforme exposto nos referidos Termos e Condições de Uso, o descarregamento de títulos de acesso restrito requer uma licença válida de autorização devendo o utilizador aceder ao(s) documento(s) a partir de um endereço de IP da instituição detentora da supramencionada licença.

Ao utilizador é apenas permitido o descarregamento para uso pessoal, pelo que o emprego do(s) título(s) descarregado(s) para outro fim, designadamente comercial, carece de autorização do respetivo autor ou editor da obra.

Na medida em que todas as obras da UC Digitalis se encontram protegidas pelo Código do Direito de Autor e Direitos Conexos e demais legislação aplicável, toda a cópia, parcial ou total, deste documento, nos casos em que é legalmente admitida, deverá conter ou fazer-se acompanhar por este aviso.

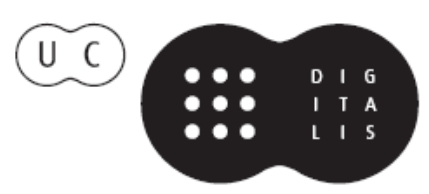


Carmen Soares

Maria do Céu Fialho

María Consuelo Alvarez Morán

Rosa María Iglesias Montiel

Coordenação

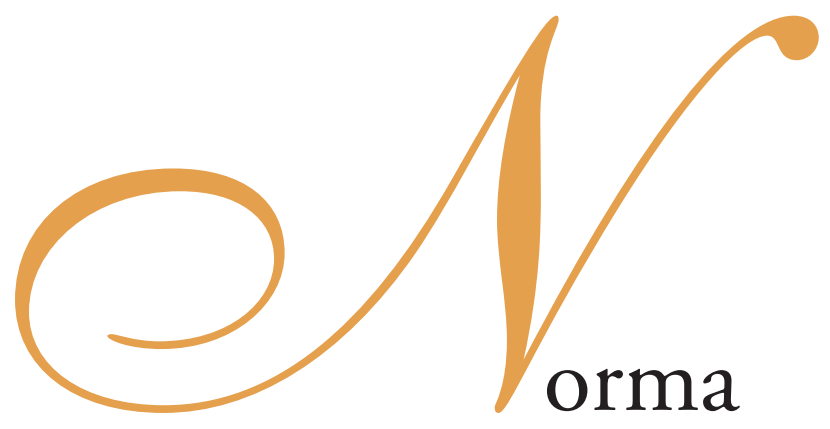

\& Transgressão

II

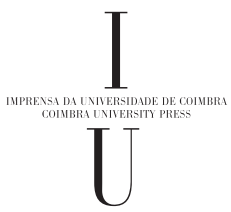


CAPítulo III

RELIGIÃO: DA GRÉCIA AOS NOSSOS DIAS 
José Augusto M. Ramos

Centro de História da Faculdade de Letras

Universidade de Lisboa

Norma E Transgressão, à luz do PARAdigma Bíblico

Por paradigma bíblico não se pretende significar nenhum tipo de normatividade que pudesse afunilar o tratamento destas duas categorias do agir humano aparentemente antitéticas. Entendemos por paradigma bíblico coordenadas que oferecem como motivo de pertinência especial o facto de se prolongarem por um tempo significativo e de implicarem um sistema de referências e valores, de sabor teológico e, por conseguinte, mais mítico e poético-literário do que puramente filosófico ${ }^{1}$. Pelo dinamismo que incutiu na vivência cultural ao longo da história este paradigma de leitura garante uma dose de representatividade bem notória.

Esta representatividade encontra-se quase ritualizada pelo facto de a literatura bíblica ter andado a constituir a base de leitura pública e oficial há mais de dois milénios, suportando no interior dessa leitura o peso da dissensão entre duas religiões, judaísmo e cristianismo, sendo que este último, sobretudo, se subdivide ainda em muitas modalidades diferentes. Essa função de leitura está na origem do conceito de Bíblia; e, tanto o judaísmo ${ }^{2}$ como o islamismo ${ }^{3}$, conservaram para os textos canónicos da sua

\footnotetext{
1 É cada vez mais incómodo pisar os terrenos resvaladiços da fronteira entre o filosófico e o poético-teológico. Para as questões atinentes ao mundo oriental, bem como para as matérias da teologia e do discurso religioso em geral, assumir esta incomodidade de forma sadia e lúcida é um passo essencial para prosseguir em bom caminho.

2 Miqrá' (leitura) é a designação corrente para identificar a Bíblia.

3 Alqur' an, Alcorão, significa leitura igualmente.
} 
leitura comunitária o nome de Leitura ${ }^{4}$. Esta prática milenar institui a leitura como essência funcional da literatura. É incomensurável a capacidade geradora de normatividades que vão decorrendo deste processo sóciocultural. Nele se processam muitas definições da prática e da teoria. É o domónio da ortopráxis e da ortodoxia, aspectos complementares entre si e com os quais se doseia a vivência cultural das comunidades de origem bíblica, incluindo neste grupo o islamismo.

Este horizonte paradigmático é ainda mais pertinente pelo facto de este tempo das leituras ser directamente perceptível pela sua longa duração. Este matiz de consciência projectada sobre uma distância histórica que desemboca no presente da leitura é sublinhado pela fórmula com que, há séculos, se costuma introduzir as perícopes de leitura evangélica na liturgia: In illo tempore,...

No horizonte deste paradigma bíblico fundamental, apresentam-se com grande destaque e representatividade tanto o conceito de norma como o de transgressão. É sobejamente reconhecido, com efeito, que a Bíblia se identifica de forma marcante com o conceito de lei e também com a ideia de pecado. Trata-se de termos correlativos. E os textos de Paulo são bem conhecidos por sublinhar fortemente essa correlação de contraste ${ }^{5}$. Estes dois conceitos fazem parte dos temas bíblicos com maior visibilidade; e são incontornáveis para definição e configuração de grande parte das matérias bíblicas.

Norma e transgressão são naturalmente percebidas como pólos correlativos. Se, pela lei, a Bíblia assume o papel de uma norma, a transgressão representa principalmente o comportamento de fuga à lei. Ambos compõem facilmente um sistema, na reciprocidade que desde a primeira impressão se lhes associa e lhes atribui a função de uma dupla fundamental no respectivo sistema de referências.

\footnotetext{
${ }^{4}$ Como a Bíblia não tem na liturgia cristã uma leitura absolutamente integral, mesmo ao longo de vários anos, existe um livro ritual que contém as leituras bíblicas destinadas aos vários perfis e a diversos ciclos litúrgicos e que, por isso, se chama o Leccionário.

${ }^{5}$ Cf. Rm 3,20.
} 
Se a lei se poderia apresentar como uma antonomásia representativa de toda a literatura bíblica, o pecado sugere, provavelmente de forma indevida, a ideia de que seria, em negativo, um legado característico ou talvez até mesmo o legado mais característico da tradição bíblica. O conceito de transgressão, no entanto, transborda largamente do conceito de pecado. E nem sempre se pode afirmar que ambos coincidem sequer no essencial.

Podemos, contudo, detectar eventualmente algumas redes de sentido que de forma surpreendente se desdobram em sistemas recheados de subtilezas à volta destes conceitos, mostrando a importância que cada um por si mesmo pode ter. A respectiva importância sistémica é de tal maneira significativa, aliás, que cada um deles constrói por sua conta um sistema de sentido autónomo do outro, por muito que mantenham aspectos de reciprocidade. Deparamo-nos até com momentos privilegiados de subtileza em que o valor que se nos impõe pode estar mais ligado a uma transgressão do que à observância de uma norma.

\section{As modulações da norma}

Para abordar a normatividade bíblica podem escolher-se muitos vectores. Para a longa duração histórica, ocorre sublinhar a normatividade que deriva do tipo de leitura pública, comunitária, litúrgica, oficial e milenar, para a qual a Bíblia oferece o texto. Já antes sublinhámos que este foi o processo através do qual realmente se constituiu e se foi configurando a própria Bíblia. A assunção pública de uma leitura é, por conseguinte, uma fonte natural de normatividade, porque mostra cumprimento de uma norma e porque institui uma fonte de novas normatividades daí decorrentes.

$\mathrm{Na}$ verdade, esta leitura definiu e regulou modelos variados de práxis; e foi igualmente configurando percursos diversos de theoria. Esta última é simultaneamente contemplação e teoria, e gera um sistema de pensamento.

Ora este facto da leitura pública e oficial constitui para nós um fenómeno cultural de longuíssima duração. São seguramente impossíveis de formular 
muitos dos pormenores e muitas das subtilezas que ao longo deste percurso se foram definindo no âmbito da leitura. Um tão amplo horizonte cultural há-de certamente oferecer pistas inumeráveis para analisar as dialécticas implicadas nos conceitos de norma e transgressão. Este processo múltiplo e matizado contém virtualidades normativas. Esta lex orandi, a norma do orar, comporta ou gera uma lex credendi, a norma do pensar crente. Estamos em pura e intensa normatividade, mesmo que lhe não corresponda uma imediata formulação legal.

Sociologicamente o cristianismo é, por conseguinte, uma religião de leitura; é, então, uma religião do livro, se bem que esta fórmula não precise de ser considerada como a assunção de uma normatividade demasiado legalista e taxativa. Com efeito, as religiões de base bíblica, assentes na leitura, são sobretudo fenómenos de cultura, com aquela variedade fenomenológica que da vivência cultural se pode esperar.

Tomada como norma, a Bíblia conhece vicissitudes e sofre o efeito de coordenadas que afectam, de modo muito variado, o seu estatuto ao longo da História. Haja em vista a modulação de concepções respeitantes ao conceito de revelação, tendendo a definir esta categoria em modalidades realísticas, como um facto histórico e apodíctico e não como o avolumar de semânticas culturais e como o adensar de dimensões com as quais se estruturam níveis de saber e de consciência. Os subtis e misteriosos caminhos do humano aparecem desta maneira mais sugestivamente formulados.

Envolvida naquela auréola de autoridade que lhe vem de ser reconhecida como Lei de Deus e pelos efeitos de subtil segregação que essa característica produz, a importância atribuída à Bíblia vai permitindo que, quase paradoxalmente, se insinue a ideia de alguma precariedade quanto ao seu estatuto de norma. Assim, ela corre o risco de ver confinada a sua representatividade apenas a um círculo de leitores e adictos ou crentes. Este processo de deslizamento para a relativização pode, de algum modo, derivar da concepção de que todas as normas são produzidas por convenção cultural e se tornam, por esse motivo, delimitadas dentro dessa mesma convenção cultural. 
Podemos detectar normatividades bíblicas múltiplas. A normatividade própria da leitura judaica é, em muitos casos, radicalmente diferente daquela que se oferece na leitura cristã, havendo variedades intermédias mais ou menos distanciadas.

Além disso, é mais estrita a normatividade bíblica acolhida no círculo estritamente eclesial. Mas é também bastante significativa a normatividade bíblica que se encontra diluída e acumulada no grande espaço cultural milenar das culturas da Europa.

Nem é preciso recorrer à referência de Europa cristã para se obterem exemplos de alguma evidência. De facto, o ritmo semanal de sete dias, que nos garante a tempo certo o saboroso fim-de-semana, é uma prática indispensável por quase todo o mundo. Ora esta é uma norma bíblica tão marcante que mereceu ser colocada como chave de abóboda, a fechar a narrativa da primeira criação do mundo ${ }^{6}$. Há, portanto, normatividades que se expandem para além do círculo estrito a que primeiro pareciam andar confinadas.

Na gama ampla de semânticas implicadas pela específica e variada história das leituras da Bíblia, o estatuto e a função normativa desta apresenta naturalmente uma grande variedade de formulações. Entretanto, uma tal panóplia de significados mais nos deveria estimular a descobrir os matizes implicados e o significado que já tiveram e que, por essa razão, ainda deveriam continuar a representar para memória e para a análise de passado. Ficarmos indiferentes ou deixar-nos escandalizar pela diferença ou pela estranheza seria a atitude menos justificada e menos produtiva.

Pouco a pouco, a leitura da Bíblia vai estando devidamente reposicionada no convívio das práticas epistemológicas e culturais. Estudá-la com os métodos científicos histórico-críticos, como se vem fazendo há mais de cem anos, ajuda a reformular e apurar as normatividades recebidas bem como a redimensionar normatividades culturais significativas, cujo significado está para além do ambiente religioso-confessional.

\footnotetext{
${ }^{6}$ Gn $2,1-4$.
} 
Esbatido, desta maneira, o ascendente social de autoridade com que tradicionalmente se processava a sua configuração, a Bíblia pode, entretanto, correr alguns riscos ainda derivados do facto de uma grande parte da sua história ter andado confinada ao espaço de uma normatividade de convenção delimitada, tanto do ponto de vista sociológico como epistemológico.

Ser vista como palavra de Deus é valorizador segundo o olhar dos crentes, mas é inevitável que seja desvalorizador para os não adeptos. O seu conteúdo sofreria de uma restrição como que confessional, sendo de algum modo irradiada dos espaços normais da epistemologia, com um estatuto diminuído. Sobrevalorizada como palavra de Deus, ficaria desvalorizada como literatura e como documento histórico.

Aquela grande e complexa metáfora a que chamamos revelação, como tudo aquilo que foi preciso teorizar intensamente em grau mais elevado, é um conceito por certo útil e cheio de significado. Ele precisa, no entanto, de se manter sob profunda e continuada reflexão. Nem se justifica repeti-lo de forma factual e realisticamente ingénua, nem cabe simplesmente marginalizá-lo, por se considerar que desse processo resulta um produto não representativo do pensar humano e das suas vivências. Tal conceito não pode servir para em seu nome irradiar uma literatura. Repensá-lo é uma obrigação, sobretudo quando se tem como tarefa analisar tudo aquilo que, de humano, foi alguma vez objecto de reflexão e formulação mais profunda. Mais ainda, quando se trata de pensamentos com tão larga representatividade colectiva e histórica.

Este risco cultural de esvaziamento de alguns sentidos normativos da Bíblia pode ter aspectos importantes. A isso nos pode conduzir o esmorecer social da evidência relativamente aos seus conteúdos e a menor identificação das pessoas com a mundividência que, apesar de tudo, lhes serve de base.

Assim reduzida ao estatuto de normatividade religiosa, uma categoria que em tempos foi concebida e proclamada como de significado universal mas que tende a eclipsar-se sem uma reformulação que lhe dê perspectivas legíveis, a ideia de norma revelada pode tender a passar despercebida e desconsiderada até mesmo na dimensão cultural que lhe competiria representar. 
Desta maneira, as características da sua identidade histórica e os acréscimos semânticos da sua ampla leitura e complexa difusão por múltiplos processos de enraizamento e de inculturação ficariam ingloriamente postos de parte, com manifestos prejuízos culturais.

A função de uma categoria como a de revelação e outras semelhantes não consistia apenas em estabelecer determinadas realidades como factos. Pelo contrário, elas pretendiam ilustrar e aprofundar determinados matizes do saber e da consciência da realidade, sugerindo para eles dimensões estruturais que os valorizavam. Ora, o valor desta perspectiva não se esgota na sentença epistemológica sobre a plausibilidade de algumas acepções que o conceito de revelação pôde, ao longo do tempo, suscitar.

Pudemos, em tempos, anotar, com agrado e também com alguma surpresa, a proposta de Karl Jaspers, na sua introdução à filosofia7, quanto ao interesse que havia em se descobrirem e valorizarem os itinerários filosóficos que, segundo ele, andam propostos e implicados nas linhas de pensamento das mais importantes correntes religiosas, nomeadamente na Bíblia, entre muitas outras análogas.

As culturas do Antigo Oriente reconheceram, de forma clara, a diferença entre normas de função imediata e normas de alcance e carácter mais profundo e estrutural ou até mesmo transcendental.

Nas primeiras, aparece codificada a normatividade legal, que é governada e garantida por meio de multas e de castigos; nas segundas, havia questões de sentido que só por meio de categorias e formas literárias de recorte mitológico se conseguiam captar e se podiam exprimir de modo satisfatório.

Entre estes dois pólos ou balizas com função normativa para o comportamento, numa relação simultaneamente autónoma mas igualmente solidária, girava todo o universo do agir humano. Neste sistema se fundamentava a moral individual e a ética política; aí assentava igualmente a dose de previsibilidade com que o homem pré-clássico justificava a sua consciência e se entregava à vida e aos seus afazeres.

\footnotetext{
7 K. Jaspers 1966: 229-232.
} 
Como exemplo disto, devemos ter em conta as coordenadas profundas de sentido para o cosmos, que aparecem formuladas nas mitologias. Estas sugerem uma ressonância profundamente diferente daquela que envolve as tais normatividades positivas, nomeadamente aquelas que se nos oferecem nalguma da legislação política conhecida na história pré-clássica.

A definição positivista da normatividade encontra-se claramente presente e, segundo parece, de forma consciente, nas leis do Código de Hamurábi. Com efeito, a actividade legislativa ou executiva ${ }^{8}$ deste rei parece ter conseguido distinguir a normatividade governativa de que trata nos seus ditames legais e os níveis míticos, religiosos ou até mesmo éticos. Este arguto legislador não mistura, contudo, o discurso de normatividade positiva, que proclama nos parágrafos casuísticos do seu código, com a ressonância mítica, também ela de intencionalidade normativa, com que se exprime no prólogo e no epílogo do mesmo código.

Esta distinção é tanto mais pertinente e meritória da sua parte quanto o próprio código de Hamurábi recorre normalmente aos materiais míticos, que marcam a mentalidade da sociedade sua contemporânea, para integrar culturalmente e legitimar politicamente a sua acção legislativa e executiva.

Há que sublinhar, no entanto, que esta distinção entre dois níveis de normatividade não pretende dar uma impressão mais superficial das normatividades de tipo prático e político. As normas práticas tinham uma gestão adequada à finalidade com que tinham sido estabelecidas. Mas não parecem, por essa razão, ser mais nem menos significativas do que a normatividade de ressonância mítica.

Sem registar exclusividade em praticamente nenhum domínio, relativamente às culturas do mundo cultural em que se encontra envolvida e com as quais foi e se mostra culturalmente cúmplice, a Bíblia desenvolveu, no entanto,

\footnotetext{
8 O código de Hamurábi poderia ser entendido como compilando decretos do grande rei. Este seria, desta maneira, o respectivo legislador. Mas é igualmente provável que o rei se tenha simplesmente servido de um conjunto de jurisprudências tradicionais e consuetudinárias, fazendo opções jurídico-políticas próprias, em circunstâncias em que foi chamado a decidir questões de direitos e de cidadania. Ver E. Bouzon 1987: 21-30; J. Bottéro 1987: 191-224.
} 
um paradigma muito específico na focagem sistémica destes dois conceitos. Apesar das compreensíveis originalidades que se lhe podem atribuir, este paradigma mantém na sua literatura muitos elementos em comum com as coordenadas da cultura pré-clássica.

Tal como, em geral, nessas outras culturas, também na perspectiva bíblica o jogo de sentidos implicados numa norma conota principalmente matizes de essência, função, estrutura, lógica, identidade, ecologia, valores e objectivos. A norma pertence mais claramente ao domínio do sentido, da intencionalidade e do valor do que propriamente da lei. Trata-se evidentemente de uma intuição sobre o núcleo dos conceitos, necessidades e interesses.

Estas variedades semânticas são, na verdade, as coordenadas da realidade e do ser, contemplado em modo de sistema; e é por elas que o mundo se sustenta em si mesmo e se nos oferece como espaço para as nossas actividades, garantindo-lhes viabilidade entre o desejável e o possível. O sentido e a coerência do mundo definem-se como lógica para o pensar e normatividade para o agir. Estas verdades asseguradas fundamentam uma visão optimista e satisfeita do mundo; e são elas que justificam o sentimento profundo que o homem pré-clássico exprime claramente, o sentimento de se encontrar de bem com a vida. É de comprazimento com o mundo que vai sucessivamente aparecendo aquele sentimento de satisfação da parte do criador ao ir declarando como era bom e até muito bom o mundo de coisas que fora criando?

Os conceitos nos quais se espelha e concentra a fundamentação do universo são realidades fundamentais $(m e)^{10}$, segundo a concepção dos sumérios; são funções e destinos (namtar / šimtu) ${ }^{11}$, para os acádicos,

9 Gn 1,10.25.31.

10 Explicamos desta maneira simplificadora um conceito que os sumeriólogos têm dificuldade em traduzir de forma concreta e apodíctica. Cf. S. N. Kramer 1972: 141-143.

11 A testemunhar a herança de pensamento sumério, o termo namtar mantém algum uso na época semítica da Mesopotâmia. No entanto, a ideia de definir a essência das coisas através da explicitação das suas funções e sentido é de tal modo nuclear na concepção do mundo que o equivalente semítico, šimtu, apresenta vastíssima utilização. Derivada de um verbo muito corrente no semítico comum que significa colocar, este substantivo feminino significa "colocação, tarefa, destino". Estamos em semântica plena das funcionalidades. Cf. J. J. Glassner 2002: 241-243. 
babilónios e assírios; é o padrão de bem, verdade, ordem e harmonia $\left(m a^{\prime} a t\right)^{12}$, para os egípcios; e é justiça (şedeq), para os hebreus ${ }^{13}$.

Estes conceitos fundamentais são os pilares sobre os quais assenta uma visão funcional, segura, confiante e, por tudo isto, satisfeita do mundo. Mas podem ser também representados por outras ideias de fundamento como as de "sabedoria"14.

Outros conceitos equivalentes ou simplesmente sinónimos se perfilham frequentemente no horizonte, como "verdade"15. E múltiplas categorias representativas da profundidade se nos apresentam a fundamentar a consistência do universo e da vida que nele desenvolviam os homens pré-clássicos, individualmente e nas aventuras de sociedade.

Ao longo da história do judaísmo, o conceito de Torá, principal expressão da sua coordenada de normatividade integral e sistémica, demonstrou sempre uma grande capacidade para se formular em termos de uma auto-consistência absoluta. É como que uma versão transcendental da Lei, como a forma lógica e a base consistente do universo. Poderá ser a percepção de consistência e de lógica enquanto postulados implícitos da intuição fundamental de existir, expressa em moldes tais que a própria sensação de conforto é a fonte geradora de evidência.

Para esta matéria, muito poderíamos certamente recolher na evolução do pensamento judaico até aos dias de hoje. Os seus contributos são, sem dúvida, notórios e dignos de atenta consideração, podendo deslizar entre

12 L. M. Araújo 2001: 524-536.

13 A maneira como Paulo, no seu intenso e característico discurso teológico, sublinhando a importância do conceito de justiça, está a utilizar num contexto de salvação um conceito que, na metafísica do seu património cultural, representava um conceito metafísico essencial.

${ }^{14}$ Um texto clássico da Mesopotâmia ao tratar um tema, também ele clássico, do sofrimento e da sensação de desconforto e de injustiça que ele suscita, designa o deus para este contexto como o "senhor da sabedoria" (bel nemeqi), expressão que tem afinidades filológicas com a raiz do semítico comum que significa "profundidade" ('mq).

15 Quando o Evangelho de João proclama de forma sonante a verdade como uma referência com a qual Jesus (Jo 1,$14 ; 8,40 ; 14,6 ; 17,17 ; 18,37$ ) tende a ser identificado não o faz numa intenção apologética de exclusividade crística no domínio da ortodoxia doutrinal. Espelha, pelo contrário, muito mais profundamente estes padrões ou postulados de fundamentação da realidade que marcam o modo de ver o mundo por parte do homem do Antigo Oriente. 
uma maneira de se representar Deus como o agente da ordem e, mais ou menos em alternativa, a Torá, representando uma ordem que é metafisicamente auto-consistente. Por outras palavras, a meditação da Torá desemboca numa contemplação da ordem do universo como um quadro feliz.

Uma expressão quase existencial da inserção de Deus numa ordem ou numa lógica que o engloba a ele próprio é, ainda no âmbito do judaísmo, aquela em que o próprio Deus se apresenta em atitude de oração pedindo ou compenetrando-se do melhor modo de se comportar ${ }^{16}$.

Mas, para além de podermos sublinhar estes valores do pensamento judaico, é particularmente interessante verificarmos que a questão se encontra já presente, e de modo decisivo, no cerne das grandes culturas do Antigo Oriente $^{17}$. De facto, podemos questionar-nos já a respeito destas culturas sobre se, em última análise, o conceito de Deus ali pressuposto é uma realidade englobante ou é uma dimensão simultaneamente englobada numa concepção integrada e unificada do universo. A questão consiste, por outras palavras, em saber se Deus está por dentro da ordem do mundo como elemento integrador mas estrutural e constituinte ou se ele se encontra por fora da mesma, sendo, neste caso, representado sobretudo como um agente desse ordenamento.

Na verdade, o conceito de Deus, no espaço de representação próprio da normatividade, joga-se como um ponto de referência que pode ser considerado como mais intrinsecamente identificado com a ordem, o sentido, a norma. Nesse caso, a sua definição processa-se sobretudo no espaço das semânticas de identidade. Mas pode também ser representado como uma realidade ou uma entidade mais exterior e autónoma, podendo ainda identificar-se com a norma, sim, mas na qualidade de seu autor.

Estas diferenças não são apenas subtilezas semânticas suscitadas pelo gosto da elucubração. Elas dependem da funcionalidade que é especificamente requerida e procurada. Por um lado, haveria uma concepção do ser em

\footnotetext{
16 A. Cohen 2002: 72 e 89.

17 Cf. J. J. Glassner 2002: 243.
} 
autonomia, mesmo utilizando um conceito de Deus coincidente com o conceito de ser. Por outro lado, estaria em jogo um conceito de ser em heteronomia, com recurso a um conceito de Deus como instrumento metafísico.

O homem bíblico parece ter sempre pendido para uma concepção de Deus visto como uma hipóstase personificada da relação heteronómica com o universo. A sua definição como extrínseco à realidade é ainda mais acentuada pela característica sensibilidade bíblica na concepção interpessoal de Deus. O absoluto é uma referência pessoal. Por definição estrutural, o tu é sempre taxativamente outro. E o outro ressoa sempre como uma referência incontornável; é um absoluto hipostático. Por estas paragens semânticas, andamos a navegar pelas águas profundas de Emanuel Lévinas ${ }^{18}$, em cujo pensamento as ressonâncias bíblicas não deixam qualquer dúvida.

Pensando bem, no entanto, esta visão heteronómica poderia facilmente reduzir-se ou reconduzir-se ${ }^{19}$ a uma visão autonómica com uma estrutura hierarquizada ou formulada em sistema relacional polarizado. Basta a subtileza de nos libertarmos do reflexo epistemológico de exprimir sob forma extrínseca as estruturas de significado da realidade, sobrecarregandoas com uma dose exagerada de realismo ingénuo. Esta estrutura realista insinua-se como metáfora de grande expressividade, mas confronta-nos com aporias difíceis de deslindar.

Em síntese, pelo caminho da norma, deparamo-nos com um tipo de vocabulário de acção que se concentra intensamente em torno dos termos "observar, guardar" (̌̌amar) ou "fazer"(‘aśab) aquilo que se encontra

18 Cf. J. L. Pérez 2008: 15. Justifica-se sublinhar as linhas que servem de entrada ao prefácio: "A subjectividade ética configura, em Lévinas, uma singular estrutura ôntica que o indivíduo adquire ao "dar-se conta" - dimensão da racionalidade - de que tem que passar pelos outros e contar com eles para poder dizer-se a si mesmo e para ser alguém; ou seja, para ter um sentido".

19 Podemos utilizar aqui o sentido bonaventuriano da reductio artium ad theologiam como uma recondução sinonímica e sem que ocorra nenhum processo de restrição semântica. Nas nomenclaturas de re-conversão em Portugal, nos séculos XVI-XVII, chamava-se "reduzidos" aos que, tendo praticado outras "religiões ou confissões religiosas" no estrangeiro regressavam ao catolicismo ao reintegrarem-se na sociedade portuguesa. Este "reduzir" vem certamente de reducere sinónimo de reconducere, significando ambos "reconduzir". A ideia não é a de diminuir, mas a de reconverter à fé inicial, mesmo que alguns daqueles conversos não tivessem anteriormente partido da religião cristã. 
estipulado como lei. É a estrutura ética da heteronomia. E assim se traduz a impressão de que é incontornável assumir as fórmulas de sentido e o modo de funcionamento que a realidade do universo coloca diante da nossa consciência e sugere ao nosso comportamento.

\section{Mais valias da transgressão}

Focados alguns pontos relativamente ao conceito de norma no horizonte bíblico, voltamo-nos agora para alguns aspectos importantes do conceito de transgressão.

Vimos com o exemplo do código de Hamurábi que a relação entre norma e transgressão mais fácil de gerir é aquela que se refere a leis concretas e taxativas.

Entretanto, existe ainda o domínio ilimitado, onde se insere toda a relação construtiva do agir humano com o universo, bem como a dinâmica pessoal da vida. Estes campos exigem frequentemente caminhos imprevistos. Por aqui, o tema da transgressão adquire uma riqueza semântica e conhece dificuldades hermenêuticas mais complexas do que as suscitadas por transgressões de normas mais concretas.

Dos múltiplos caminhos possíveis, optamos por sublinhar alguns matizes relativos ao conceito de transgressão, tecendo considerações sobre determinadas valências do seu significado. A sua relação com o conceito de norma apresenta dimensões curiosamente dialécticas, recuperando razões de sintonia e de convergência entre ambas, mesmo que, no essencial, ambas se possam apresentar em contraposição.

Enquanto o conceito de norma insistia em comportamentos de obediência, neste conceito de transgressão, parece detectar-se uma dose muito maior de semânticas de criatividade, a julgar pelo léxico bem diversificado que a questão suscita. Com efeito, os sentidos da transgressão, para além do aspecto mais imediato de anomia ou de desvio à norma, nas várias formas e ocorrências com as quais se define a sua própria fenomenologia, acabam 
por condizer intensamente com as dialécticas de recorte claramente individualizado e com as características existenciais do agir.

Ou seja, a transgressão é um desvio relativamente à norma, mas ela contém uma dose específica de afirmação e intensidade, que acentuam a identidade do agente. Nesta dialéctica do agir, aparece concentrado o processo criador, definindo sentidos e formulando interesses e valores. Estes podem ser inteiramente novos ou apenas antigos valores reformulados. Em suma, a norma está mais voltada para o cuidado dos valores que existem. A transgressão pode carregar em si o desafio e a urgência de criar valores novos.

Ocorre por esta via um processo de recriação, reformulando desta maneira algumas dimensões do ser e promovendo outras que antes não existiam. É neste sentido criativo e criador que o agir humano é visto como imagem e semelhança da acção instituidora de Deus. Mais do que criar repetindo realidades fixas, completas e perenes, a acção criadora de Deus é apresentada como que a instituir ou mesmo a institucionalizar seres com funções analogamente criativas. Segundo Gn 1, 26-28, as dimensões humanas essenciais do agir são expressas pelos verbos de acção, nomeadamente frutificar em procriação, crescer em nascimentos e gerir bem a utilização da terra. É nisto que o homem é e se comporta verdadeiramente como imagem de Deus.

Ora, criar consiste precisamente em definir e instituir novas funcionalidades e novos sentidos. Com efeito, a norma é a maneira correcta e eficaz de se realizar uma função que tem sentido, de cumprir o caminho que se impõe. A norma é o que está pré-determinado na definição dos objectivos. A linguagem mesopotâmica dos sentidos decretados como destinos exprimia esse aspecto com toda a clareza.

Algo desta semântica de transgressão se encontra ínsita, resguardada e quase prometida na própria originalidade do criar. A criação é uma ruptura. Nesta perspectiva e sem nenhuma intenção de exagerar em rasgos de anarquia, a transgressão é uma parte integrante do agir, tão pertinente como a observância, e pode, como já se disse, constituir um autêntico acto de criação.

Um pouco de filologia no espaço semântico de um verbo hebraico ligado à criatividade pode ajudar-nos a sublinhar aquilo que estamos a tentar 
mostrar. O verbo yaşar, que significa "formar" ou "modelar", é naturalmente utilizado como um dos sinónimos de "criar". Dele deriva o conceito de força motriz do agir humano, o impulso que lhe conduz a acção. Este impulso subdivide-se em yeşer ţov ou yeşer rá. O primeiro é um impulso de acção bom; o segundo, um impulso de acção mau. Esta classificação axiológica depende do comportamento em causa, avaliado pelos padrões da norma ${ }^{20}$.

O agente humano institui-se, desta maneira, como um criador de alternativas, até por meio das suas transgressões. Seria exagerado suspeitar de um tal acréscimo de criatividade na transgressão? Os sentidos alternativos para as coisas podem, por conseguinte e na própria lógica deste agir, ter de se assumir como uma transgressão, uma acção pela qual se institui uma rota desviante relativamente à norma pré-determinada. Qualquer criação é, aliás, ir mais além do limite criado anterior; é ultra-passar e trans-gredir.

Algum deste efeito de caos que o agir transgressivo pode instaurar retoma, com todo o direito, as conotações, ao mesmo tempo, desconcertantes e promissoras $^{21}$ que o caos mítico das origens continha. E, tal como acontecia com aquele caos primordial, também este novo caos emergente se constitui como berço e semente para uma nova ordem.

Poderia até dizer-se que nisto se encontra o $b$ - $a$-bá da síntese de metafísica que se nos propõe na mitologia fundamental do mundo pré-clássico. O caos é mítico e primordial não por ser o momento primitivo, mas porque é uma situação perenemente primordial. Caos e ordem são coordenadas paralelas de um processo de criação contínua. As mitologias de origem contêm coordenadas de metafísica universal.

É lógico considerar que o caos descrito nas narrativas antigas de criação constitui em si mesmo um estado de transgressão transcendental, aqui no sentido negativo da transgressão, uma vez que se contrapõe de forma absoluta ao funcionamento em perfeita ordem que é uma tautologia de

\footnotetext{
20 Cf. Ver G. Wigoder 1996: 481; E. E. Urbach 1971: 415-427; A. Cohen 2002: 188-197.

21 Cf. José Ramos 2008: 59-67.
} 
mundo. Por isso, o deus criador combate contra este estado caótico de transgressão.

As narrativas de transgressão, no contexto dos mitos de origem, podem também definir alguns limites que obsessivamente se enfrentam como desafio de afirmação e de crescimento humano. Mais forte do que as sentenças sobre o pecado de se ultrapassar o limite proibido, o lado irrenunciável da transgressão sublinha horizontes profundamente incrustados no património humano dos desejos. É por aqui que se compreende o sentido da transgressão relativamente à árvore de conhecer o bem e o mal e à árvore da vida, que se encontrava no meio do jardim do Éden ${ }^{22}$.

A mesma coisa se pode dizer da ambição em construir a torre de Babel ${ }^{23}$ e do frenesim com que se empreende a busca da imortalidade. Esta última é uma saga bem conhecida pela epopeia de Gilgamesh ${ }^{24}$, mas ela deixou igualmente indícios bem assinalados em todas as literaturas do antigo Oriente ${ }^{25}$. Conquistar a vida eterna é, com efeito, o exemplo da mais transgressora utopia que atravessa a sensibilidade antropológica das culturas pré-clássicas.

De facto, a norma evidente era a de que os deuses deram a vida aos homens, mas retiveram a vida eterna para $\mathrm{si}^{26}$. E também na Bíblia ficaram indícios numerosos de como os hebreus foram sensíveis aos temas antropológicos da imortalidade ${ }^{27}$.

Em qualquer destes três casos, consituindo um tipo de transgressão que podemos designar transcendental, está em causa a ideia de os homens poderem ser como deuses, atingindo os céus, ou de conseguirem o estado de imortalidade como os mesmos deuses. É a transgressão como estratégia de transposição ou como movimento de superação da condição humana.

\footnotetext{
22 Gn 3,1-13.

23 Gn 11,1-9.

24 J. Bottéro 1992: 182 (X, 30).

25 F. M. T. de Liagre Böhl 1977: 237-275.

26 R. Labat 1970: 205, citando uma das antigas versões de Gilgamesh.

27 E. Jacob 1962: 688-690.
} 
Estas histórias de transgressão são analisadas do ponto de vista do sonho anterior e das suas consequências antropológicas posteriores de frustração. Não se dá pertinência ao tema da culpa. É o relato de uma hipótese de transgressão não culpabilizada.

Por outro lado, a grande transgressão adâmica como origem e justificação de uma espécie de condição pecaminosa natural para todos os humanos parece conter mais definições provenientes da história da leitura do que da sua base mítica propriamente dita sobre a transgressão primordial ${ }^{28}$.

Entretanto, o conceito de Deus define-se biblicamente no horizonte da transgressão, não tanto com a simples função de juiz, mas como o detonador de uma outra dialéctica que está implicada no agir humano; é a sua dimensão de dialogalidade interpessoal, que permite definir uma dupla imputabilidade do agir. Por um lado, é a imputabilidade pela via do eu enquanto agente incontornável e assumido. Por outro lado, é a imputabilidade pela via do tu absoluto, como natural testemunha transcendente do eu agente.

A acção transgressiva é auto-nómica, por evidência e por definição. Ela é, no entanto, dependente e comprometida no âmbito da dita relação interpessoal que pode ser caracterizada como uma relação mais de cumplicidade que de solidariedade. O "meu acto", apesar da carga de autoafirmação que exibe, mostra também a necessidade de ser reconhecido e é dessa maneira que ele passa a ser autenticado e confirmado pelo meu Tu. Qualquer criador precisa de suscitar adeptos ou adoradores. A sua omnipotência mendiga louvor. O agente humano transgressor/criador não foge à regra.

Poderíamos até considerar que, na perspectiva bíblica, o espaço mais significativo de Deus se situa no domínio do agir humano, cumprindo desta maneira a função estrutural de um Tu transcendental, mais do que no domínio da metafísica do ser em si, formulado mais facilmente com a função de criador. A fórmula preferiu uma metafísica da física à metafísica da consciência.

\footnotetext{
28 A. Vaz 1996: 257-279.
} 
Talvez isto nos possa confirmar a ideia já referida de que é na esfera do agir que o homem bíblico vai descobrir o verdadeiro espaço para a criatividade e que esta é uma das chaves de que se serve para abrir a porta e se introduzir no mistério do agir humano.

Segundo o texto já referido de Gn 1, 26-28, são os verbos de acção, nomeadamente os de frutificar sexualmente, crescer demograficamente e dominar ecologicamente o mundo, aqueles com que se exprime a semelhança do homem para com o modelo de Deus, partilhando assim ambos a imagem de criadores. É por toda esta gama de criatividades que o homem deve ser considerado como imagem do criador. E podemos verificar que esta metáfora não é fútil.

Aqui se encontra o epicentro para uma das principais dimensões que se podem descobrir na "filosofia" bíblica a respeito do pecado. Por esta perspectiva, a própria desordem aparece valorizada como construtora de um novo ordenamento; e com este conseguiu-se um patamar inquestionavelmente superior. Uma nova ordem se formulou, tomando como ponto de partida a transgressão acontecida.

As características de uma história de transgressões enriquecedoras passaram a constituir o tecido de uma história de salvação. E esta ganhou uma tal qualidade que já não era desejável renunciar a essa conquista. A imagem de uma história da transgressão com a correspondente resolução, culminando com a declaração de redenção total, tornou-se mais brilhante do que a de uma simples e apagada observância da norma. É claro que a valorização da transgressão que, nesta secção, temos estado a fazer é paralela e não exclusiva daquilo que se disse na secção anterior sobre a importância da norma e do seu cumprimento. A relação é dialéctica, como se disse, e não deve ser mutuamente prejudicial.

O eco derivado da primitiva transgressão serviu de base a posteriores construções tão envolventes e tornou-se de tal modo incontornável que passou a ser considerado teoricamente imprescindível. É um mito fundador do agir humano.

A figura de um messias redentor tinha que ser postulado, em nome do significado atingido por esta figura na história, mesmo que Adão, por 
hipótese académica, não tivesse iniciado a história do pecado. Esta subtilíssima elucubração, em que a teologia escolástica se comprazia, constitui aquele exercício demonstrativo subtil e engenhoso, que se poderia designar como sendo uma passagem pelo irreal, uma espécie de utopia em tempo passado, que seria mais hipótese académica do que desiderato. Esta imagem irreal, no entanto, implica a formulação da história humana em alternativa, com duas modalidades extremadas da condição humana, aquela que seria a teoricamente natural e a decaída e redimida ${ }^{29}$.

Este estranho comprazimento com a transgressão aparece num singular texto proclamado ao início da vigília pascal, num contexto literário e semântico que tem como tema o processo contínuo de criação e libertação conducente à Páscoa da redenção. Nisto consiste e se desenvolve toda a história do mundo. O texto celebra desta maneira exultante a transgressão de Adão:

O certe necessarium Adae peccatum, quod Christi morte deletum est.

O felix culpa, quae talem ac tantum meruit habere redemptorem ${ }^{30}$.

Esta aparente reviravolta na atitude a respeito da norma acentua bem a dimensão interpessoal adquirida sobre a transgressão e o pecado. É a concepção nuclear da história da salvação como articulação entre a ideia de transgressão e a de incarnação de um redentor. Este percurso tornou-se incontornável como fórmula de uma epopeia histórica. E, segundo esta perspectiva, não existe outra história senão aquela que cabe entre estes dois pólos de transgressão e redenção. É a única história humana real.

29 Os novos catecismos cristãos de adultos, que caracterizam o pensamento cristão da segunda metade do século XX, foram repropondo uma espécie de escolástica pastoral. Esta imagem de dupla condição humana entre o teórico e o real histórico com transgressão e redenção. O chamado catecismo holandês acolhe essa referência num parecer da comissão cardinalícia, porque o texto propriamente dito não o explicitava tanto ( $O$ novo catecismo: a fé para adultos: na página 9 não numerada do parecer inicial; e nas pp.307, 313). Cf. ainda J. Feiner e L. Vischer 1976: 277; R. Lawler; D. W. Wuerl, T. C. Lawler 1981: 77. O Catecismo da Igreja Católica 1993: 99-102 tem particular representatividade por estar baseado nos documentos do Concílio Vaticano II e ter sido promulgado por João Paulo II.

30 F. Villa Rivera 1961: 386. 
Assim se define uma versão da história, colorida e recheada com as tonalidades épicas de uma história da salvação. Esta concepção tem muita visibilidade e grande ressonância no discurso bíblico e acabou por representar o cerne do discurso religioso, tanto judaico como cristão. Esta imagem da história assenta precisamente nas virtualidades empolgantes, derivadas de uma história pavimentada de transgressões em contínuo processo de resolução. Aquilo que poderia ser uma história de castigos transforma-se numa história de reconciliação, por via da dialéctica de um castigo que é dado por amor e é igualmente acolhido com amor $(\operatorname{Pr} 3,12)$.

Isto lembra os subtis movimentos de dialéctica de sentimentos, por entre os quais um casal de amorosos vai progredindo, de ofensa em reconciliação, num crescendo de paixão que a própria transgressão parece compensar. O Félix culpa - caberia aqui dizer, de igual modo, também. Biblicamente, a imagem da história é explicitamente passional ${ }^{31}$.

Eventualmente, elementos procedentes desta dialéctica de amor-castigo podem ter levado a exacerbar o sofrimento necessário na zona discursiva e imagética de um redentorismo cristão de gosto muito popular em tradições de Semana Santa, o qual, do tema do pecado, se preocupa em tematizar sobretudo o lado amartológico e sublinha particularmente as sequelas doloristas do resgate. Haja em vista as versões algo caricaturadas e até simplórias frequentemente referidas por José Saramago, de modo muito particular no seu famoso romance Evangelho segundo Jesus Cristo ${ }^{32}$.

A cadeia de leituras da Bíblia transmitiu uma versão particularmente negativa da transgressão original, como acontecimento constituinte da actual condição humana e fundamento para a respectiva metafísica. É a categoria

31 O capítulo 16 de Ezequiel é um belíssimo relato de uma história inteira de paixão entre Deus e Jerusalém, colocado na boca de Deus.

32 Saramago repete esta análise em chavão universal. Pode ver-se, à saciedade, no Evangelho segundo Jesus Cristo. Em termos de conteúdo, estou a referir-me à imagem geral de redentorismo, segundo um desígnio autocrático de Deus sobre Jesus, com cores drásticas e facilmente classificáveis como absurdas. Intui-se que a construção desta imagem procura a tautologia de evidência fácil. Mas o facilitismo não credibiliza a argumentação. Designámos de redentorismo esta concepção de redenção, porque ela contém evidentemente ingredientes doentios. 
do pecado original. Esta teve possibilidade de utilizar formas embrionárias da textualidade bíblica, dependendo mais das virtualidades imagéticas das origens. Entretanto, a ideia foi intensamente elaborada na história das suas leituras, múltiplas, intensas e cada vez mais taxativas ${ }^{33}$.

Uma história humana marcada pelo pecado original tem a particularidade de, nas produções da teorização cristã, ter representado a metafísica real ou natural, aquela com que historicamente se define, formula e avalia o humano e até mesmo o universo, tal como o conhecemos e vivemos. Era a natureza humana decaída. Em contraponto a esta condição natural, pairava num horizonte distante e saudoso uma metafísica alternativa, onde a imagem da condição humana era sobrelevada acima da natureza, era sobrenatural. Esta segunda poderia projectar-se como sendo uma visão de cunho mítico, como uma perspectiva sobre-humana.

Em comparação com a observância da norma, a transgressão tem muitos nomes; pode mesmo ser legião, como no caso do demónio interpelado por Jesus $^{34}$. O termo 'averáh é uma ultrapassagem normalmente indevida de uma norma ( $\hbar \circ q$ ), como quem sai para fora de um marco no caminho. Uma rápida consulta a um dicionário de semânticas, mesmo só do Novo Testamento, mostra-nos que a semântica relativa a qualidades morais e éticas relacionadas com o comportamento humano se subdividem em tantas alíneas que a lista decorrente ocupa o espaço de quase dois alfabetos ${ }^{35}$.

Religiosamente, ela implica um desafeiçoamento e afastamento para com Deus. Por modestos que sejam eventualmente os seus pecados, o filho pródigo $^{36}$ é o grande pecador, porque a sua imagem define um tipo de afastamento de conotações biblicamente intensas.

Pelo contrário, a conversão ou arrependimento, em hebraico teshuváh, é um movimento de regresso. Por um lado, é o regresso ao ponto de onde,

\footnotetext{
33 Um apanhado histórico e sintético das discussões contemporâneas sobre o pecado original pode se encontrado em A. Villalmonte 1978: 551-556

34 Lc 8,30 .

35 Cf. J. P. Low; E. Nida (eds.), 1993, 742-743.

36 Lc 15,11-32.
} 
com a transgressão, tinha começado o desvio; por outro lado, é o regresso ao encontro com alguém relativamente a quem a transgressão representara um afastamento. A reconciliação é, antes de tudo, um reencontro pessoal, possivelmente um encontro de conteúdo realmente novo, integrando já a novidade que o processo de transgressão despoletou.

Ficaram de fora, por razões de economia de meios, as considerações sobre a questão da sanção. Ela é certamente pertinente nesta relação entre norma e transgressão, mas torna-se complexa do ponto de vista da instauração da ética bíblica sobre o tema.

Com efeito, a relação imediata e estrutural entre norma e transgressão levou-nos de preferência a sublinhar a importância dos aspectos ontológicos do agir que, por estranho que possa parecer, se exprimem nas vivências da transgressão com uma pertinência não menos significativa do que aquela que vemos realizar-se na simples observância das leis.

É certo que a norma apenas atribui valor à observância, porque esta confirma e valida os objectivos das leis, enquanto a transgressão dialecticamente se lhes contrapõe. É a contemplação de todo o dinamismo que envolve o agir humano que nos faz descobrir cumplicidades inesperadas entre os comportamentos de conformação à norma e os comportamentos de transgressão a algumas normas em concreto.

Existe, no entanto, um género de transgressão bem mais radical e pertinente. Um processo de transgressão pode instaurar-se como uma revolução dialéctica, de modo a garantir uma mais profunda fidelidade para com um núcleo mais autêntico da normatividade. Está aqui o lugar de nascimento do espírito, em que a norma se transfigura. O calor e a controvérsia com que esta transgressão é recebida traduzem normalmente o contraste de razões e de sentidos que se encontram contraditoriamente implicados nesse passo. Este salto inaudito é transgressão e criatividade e pode até constituir um caso da mais autêntica fidelidade. 
A Carta aos Gálatas ${ }^{37}$, enquanto manifesto da novidade cristã segundo a interpretação de Paulo, pode ser um belíssimo exemplo desta atitude e comportamento radicais. A dialéctica entre lei e transgressão é uma dimensão importante representada pelo discurso de Paulo de Tarso, cujo bimilenário se convencionou celebrar por estes anos.

As complexidades implícitas na hermenêutica com que Paulo lê o Antigo Testamento deixam-nos a convicção de que a lei de Moisés e o seu espírito, apesar de falar disso em tonalidades de contraposição radical, podem ainda constituir versões dialécticas de uma mesma realidade e até mesmo de um só plano. A gestão do itinerário entre estes dois pólos da realidade não consegue evitar, num momento de intensidade e de algum drama, a opção necessária pela transgressão, mesmo com o sofrimento que tal passo certamente implica. E, mesmo que nesta conversão possam ter relevância clara muitos aspectos obedienciais, a própria conversão se nos apresenta com tonalidades e desgarramentos que podem caracterizar uma transgressão transcendental.

A hermenêutica é o espaço onde se realiza e se vai resolvendo esta dialéctica. A conversão de Paulo traduz imageticamente o seu percurso entre duas normatividades com versões contraditórias, a letra e o espírito, a lei e a liberdade, o antigo e o novo. A unidade da Bíblia é, deste modo, dialéctica. E toda a hermenêutica o será também, provavelmente.

\section{Bibliografia citada}

L. M. Araújo (2001), "Maet", in L.M. Araújo (ed.), Dicionário do Antigo Egipto, Lisboa, 524-536.

J. Bottéro (1987), Mésopotamie. L'écriture, la raison et les dieux, Paris.

J. Bottéro (1992). L'epopée de Gilgamesh, Paris.

E. Bouzon (1987), O Código de Hammurabi, 4ª ed., Petróplis.

Catecismo da Igreja Católica ( 1993), Coimbra.

37 A famosa proclamação de Gl 3,28 de que "não há judeu nem grego; não há escravo nem livre; não há homem nem mulher, porque todos sois um só em Cristo Jesus" transgride evidentemente várias normatividades importantes. 
A. Cohen (2002), Le Talmud, Paris.

J. Feiner; L. Vischer (1976), O novo livro da fé: a fé cristã comum, Petrópolis.

E. Jacob (1962): "Immortality", in The interpreter's dictionary of the Bible, New York, 688-690.

K. Jaspers (1966), Introduction à la philosophie, Paris.

S. N. Kramer (1972), Os Sumérios, Lisboa.

R. Labat (1970), Les religions du Proche Orient asiatique, Paris.

F. M. T. de Liagre Böhl (1977), "Das Problem ewigen Lebens im Zyklus und Epos des Gilgamsh", in K. Oberhuber, Das Gilgamesh Epos, 1977, Darmstadt, 237-275.

R. Lawler; D. W. Wuerl; T. C. Lawler (1981), A mensagem de Cristo: catecismo católico para adultos, Coimbra.

J. P. Low; E. Nida (eds.), (1993), Greek-English Lexicon of the New Testament, based on semantic domains, Cape Town.

O nôvo catecismo: a fé para adultos (1969), São Paulo.

J. L. Pérez (2008), Émmanuel Lévinas: Humanidade e Razão, Lisboa.

J. A. Ramos (2008), "Metaforicidade humana do mar pre-clássico", em Cadmo 18, 53-80.

E. E. Urbach (1971), The sages: their concepts and beliefs, Jerusalém (em hebraico).

A. Vaz (1996), A visão das origens em Génesis 2,4b-3,24, Lisboa.

F. Villa Rivera (1961), Liber Chori, Barcelona.

A. de Villalmonte (1978), El pecado original: veinte y conco años de controversias (1950-1975), Salamanca.

G. Wigoder (1996), Dictionnaire encyclopédique du judaïsme, Paris. 


\section{Série}

\section{Documentos}

Imprensa da Universidade de Coimbra

Coimbra University Press

2011

- $\mathrm{U}$

C • 